\title{
The Treatment of Chronic Graft-Versus-Host Disease
}

Consensus Recommendations of Experts From Germany, Austria, and Switzerland

Daniel Wolff, Hartmut Bertz, Hildegard Greinix, Anita Lawitschka, Jörg Halter, Ernst Holler

\section{SUMMARY}

Background: Chronic graft-versus-host disease (cGVHD) is the commonest complication of allogeneic bone marrow and blood stem-cell transplantation, occurring in $50 \%$ of all cases and causing late mortality in as many as $25 \%$. There are now about 10000 patients with cGVHD in Germany, and their number is growing by about 500 each year. CGVHD is a chronic multisystem disease due to impaired tolerance mechanisms. It affects many organs in variable ways, impairing organ function and lowering quality of life.

Methods: We present consensus recommendations on the treatment of CGVHD that were developed jointly by the German Working Group on Bone Marrow and Blood Stem-Cell Transplantation, the German and Austrian Societies of Hematology and Oncology, the Swiss Blood Stem-Cell Transplantation Group, and the German-Austrian Working Group on Pediatric Stem-Cell Transplantation. All of the recommendations are based on an evaluation of selected publications .

Results: Recommendations are given regarding the diagnostic evaluation of CGVHD, first-line treatment (which has a response rate of $30 \%$ to $50 \%$ ), secondline treatment, and topical immunosuppression. Patients with cGVHD should also receive supportive care including anti-infective prophylaxis, vaccinations, hormone replacement, prevention and treatment of osteoporosis, physiotherapy, rehabilitation, and psychosocial assistance.

Conclusion: Patients with cGVHD need multidisciplinary care under the guidance of the transplantation center. The aim of these recommendations is to standardize the treatment of CGVHD and thereby improve patient care.

\section{Cite this as:}

Wolff D, Bertz H, Greinix H, Lawitschka A, Halter J, Holler E: The treatment of chronic graft-versus-host disease: consensus recommendations of experts from Germany, Austria, and Switzerland. Dtsch Arztebl Int 2011; 108(43): 732-40. DOl: 10.3238/arztebl.2011.0732
Abteilung für Hämatologie und klinische Onkologie, Universität Regensburg, Deutschland: Prof. Dr. med. Wolff, Prof. Dr. med. Holler

Medizinische Universitätsklinik, Abteilung für Hämatologie und Onkologie, Albert Ludwig Universität Freiburg, Deutschland: Prof. Dr. med. Bertz

Klinik für Innere Medizin I, Medizinische Universität Wien, Österreich: Prof. Dr. med. Greinix

St. Anna Kinder Spital, Wien, Österreich: Dr. med. Lawitschka

Abteilung für Hämatologie/Stammzelltransplantationsteam, Universitätsspital Basel, Schweiz: Dr. med. Halter
C hronic graft-versus-host disease (cGVHD) is a frequent cause of morbidity and subsequent mortality (approximately 25\%) following allogeneic hematopoietic stem-cell transplantation (allogeneic HSCT) (1, 2). Its incidence is approximately 50\% among all patients following allogeneic HSCT and has risen during the last decade due to increasing patient age, increasing use of unrelated donors, the use of dosereduced conditioning regimens, and the use of peripheral blood stem cells (3).

While the incidence of cGVHD is lower $(20 \%$ to $30 \%$ ) in children, its incidence rises to $60 \%$ as age increases. This results in a prevalence of approximately 10000 patients in Germany, which increases by approximately 500 per year (e1).

The pathophysiology of cGVHD is characterized by impaired tolerance mechanisms (i.e., reduced thyroid function, dysfunction of regulatory T cells). Both autoreactive and alloreactive $\mathrm{T}$ and $\mathrm{B}$ lymphocytes play a role (4). Other pathophysiological factors are indirect presentation of alloantigens through antigen-presenting donor cells and mechanisms of chronic inflammation with subsequent scar formation.

A major risk factor for cGVHD is a history of acute GVHD. The incidence of acute GVHD following allogeneic HSCT is approximately $30 \%$ to $60 \%$.

In addition to the harm it causes, cGVHD also has a protective effect, as patients with cGVHD have lower rates of recurrence of their underlying malignant disease. Overall survival of patients with mild cGVHD is therefore better compared to patients without cGVHD. Even overall survival of patients with moderate cGVHD is not different from patients without cGVHD, as the slightly increased mortality associated with cGVHD is counterbalanced by lower diseaseassociated mortality (2). In contrast, the long-term mortality rate of patients with severe cGVHD is as high as $50 \%$. Despite the great clinical significance of cGVHD, few advances have been made in its diagnosis and treatment during the last 20 years.

\section{Methods}

A consensus conference on the clinical treatment of cGVHD was held in autumn 2009, under the auspices of the German Working Group on Bone Marrow and 
Blood Stem-Cell Transplantation (DAG-KBT, Deutsche Arbeitsgemeinschaft für Knochenmark- und Blutstammzelltransplantation), the German and Austrian Societies of Hematology and Oncology (DGHO and ÖGHO, Deutsche Gesellschaft für Hämatologie und Onkologie and Österreichische Gesellschaft für Hämatologie und Onkologie), the Swiss Blood Stem-Cell Transplantation Group (Schweizer Blutstammzelltransplantations-Gruppe), and the German-Austrian Working Group on Pediatric Bone Marrow and Blood StemCell Transplantation (PÄD-AG-KBT, DeutschÖsterreichische Arbeitsgemeinschaft pädiatrische Knochenmark- und Blutstammzelltransplantation). At this conference, recommendations on the diagnosis, immunosuppressive treatment, and supportive therapy of cGVHD in routine clinical practice were developed, aiming to improve clinical care for patients with cGVHD. The evaluation of evidence and the subsequent recommendations were graded according to international standards which have already been applied for the NIH consensus of cGVHD in 2005 (NIH-US National Institute of Health) (5). The literature search was performed by the participants of the working groups within the Consensus conference using the Pubmed database. Only English-language literature published up to 2010 was considered. Conference contributions were also collected but were not included in grading of the evidence.

\section{Clinical manifestations}

cGVHD usually begins between three months and two years after transplantation, but earlier onset (at least one month after transplantation) is possible (6). cGVHD can imitate almost any autoimmune disease, such as myasthenia gravis and myositis (e2). As cGVHD can affect a number of organs, and patients often do not report changes until functional impairment is recognized, regular examination of all organs potentially affected is essential. The following section describes the most common clinical organ manifestations of cGVHD.

\section{Skin}

During the early phase of cGVHD skin manifestations may occur with a lichen planus like morphology or maculopapular rash. Other symptoms are poikiloderma and cutaneous alterations similar to scleroderma (morphea-like sclerosis), increased ichthyosis, and hypo- or hyperpigmentation. Later on, lichen sclerosus or sclerodermoid cutaneous alterations with deep cutaneous sclerosis may appear. Loss of skin appendages is also possible (e3) (picture atlas available at www.gvhd.de).

\section{Eyes}

cGVHD of the eyes usually manifests as keratitis sicca. In addition to atrophy of the lacrimal gland with subsequent tear deficiency (sicca syndrome), the meibomian glands and eyelids are often affected by severe blepharitis. Around the conjunctiva there are often not only

\section{TABLE 1}

Grading of severity of chronic graft-versus-host disease (cGVHD) (according to [6])

\begin{tabular}{l|l|l|l|}
$\begin{array}{l}\text { Severity of cGVHD } \\
\begin{array}{l}\text { Number of affected } \\
\text { organ systems }\end{array}\end{array}$ & Mild & $>2$ & $>2$ \\
\hline $\begin{array}{l}\text { Severity of organ } \\
\text { manifestations }\end{array}$ & $\begin{array}{l}\text { Mild } \\
\text { (excluding lung) }\end{array}$ & $\begin{array}{l}\text { Mild-moderate } \\
\text { (lung: mild only) }\end{array}$ & $\begin{array}{l}\text { Severe } \\
\text { (lung: moderate } \\
\text { or severe) }\end{array}$ \\
\hline
\end{tabular}

fibrotic alterations but also chronic persistent inflammation with visible erythema of the conjunctiva (e4).

\section{Oral mucosa}

Oral manifestations may appear as erythema or lichenoid changes of the oral mucosa as well as ulcera and mucoceles. Sicca symptoms may result from destruction of the salivary glands. Long-term cGVHD leads to gingivitis, periodontitits, increased tooth decay, and tooth loss (e5).

\section{Liver}

Liver involvement manifests as cholestasis and may resemble primary biliary cirrhosis, but hepatitic forms with high transaminases are also possible (e6, e7).

\section{Gastrointestinal tract}

Gastrointenstinal manifestations can lead to dysphagia (esophagus), nausea and vomiting (stomach), or chronic diarrhea and malabsorption syndrome (intestines, pancreas) (e8).

\section{Genitals}

The symptoms of cGVHD are similar to those of vaginal lichen planus. Synechiae, ulceration, and fissures can subsequently occur. Vaginal manifestations are often associated with oral manifestations of cGVHD (e9).

\section{Lung}

Pulmonary manifestations occur as progressive, irreversible obstruction (bronchiolitis obliterans), and less frequently lymphocytic alveolitis resulting in interstitial fibrosis or bronchiolitis obliterans organizing pneumonia (BOOP) (e10).

\section{Joints and fasciae}

cGVHD-associated fasciitis can result in restricted mobility of large joints. This can also be caused by deep cutaneous sclerosis. Moreover, rheumatoid complaints may be associated with cGVHD (e11, e12).

\section{Diagnosis}

cGVHD is diagnosed on the basis of symptoms associated with cGVHD, laboratory values (for hepatic manifestations), and examination of pulmonary function (6). 
First-line therapy for chronic graft-versus-host disease (cGVHD) (according to [8])

\begin{tabular}{|c|c|c|c|c|c|}
\hline Drug & $\begin{array}{l}\text { Recommen- } \\
\text { dation grade }\end{array}$ & $\begin{array}{l}\text { Level of } \\
\text { evidence }\end{array}$ & $\begin{array}{l}\text { Side effects in more } \\
\text { than } 25 \% \text { of treated } \\
\text { patients }\end{array}$ & $\begin{array}{l}\text { Response } \\
\text { rate }\end{array}$ & Comments \\
\hline Steroid & $A$ & I & $\begin{array}{l}\text { Osteoporosis, } \\
\text { osteonecrosis, } \\
\text { diabetes mellitus }\end{array}$ & $\begin{array}{l}\sim 30 \text { to } 50 \% \\
\text { CR }\end{array}$ & $\begin{array}{l}\text { The main drug in cGVHD therapy; } \\
\text { strategies to reduce use due to } \\
\text { SEs very important }\end{array}$ \\
\hline $\begin{array}{l}\text { CNls combined with } \\
\text { steroids }\end{array}$ & C-1 & ॥ & $\begin{array}{l}\text { Renal toxicity, } \\
\text { hypertension }\end{array}$ & $\begin{array}{l}\sim 30 \text { to } 50 \% \\
\text { CR }\end{array}$ & $\begin{array}{l}\text { Reduces steroid use, reduced } \\
\text { incidence of osteonecrosis }\end{array}$ \\
\hline $\begin{array}{l}\text { MMF combined with } \\
\text { steroids }\end{array}$ & C-1 & || $\mid-2$ & $\begin{array}{l}\text { GI complaints, } \\
\text { infections }\end{array}$ & $\begin{array}{l}\sim 30 \text { to } 50 \% \\
\mathrm{CR}\end{array}$ & $\begin{array}{l}\text { Increased risk of viral infection, } \\
\text { associated with steroid sparing } \\
\text { activity }\end{array}$ \\
\hline $\begin{array}{l}\text { MMF combined with } \\
\text { CNI and a steroid }\end{array}$ & D & ॥ & $\begin{array}{l}\text { GI complaints, } \\
\text { infections }\end{array}$ & & $\begin{array}{l}\text { No increased efficacy compared } \\
\text { to CNI and steroids, increased } \\
\text { risk of relapse of malignancy }\end{array}$ \\
\hline Azathioprine & D & ॥ & $\begin{array}{l}\text { Cytopenia, } \\
\text { risk of infection }\end{array}$ & & Increased mortality \\
\hline Thalidomide & D & $\|$ & $\begin{array}{l}\text { Neurotoxicity, drows- } \\
\text { iness, constipation }\end{array}$ & & $\begin{array}{l}\text { Very little effect in first-line } \\
\text { therapy }\end{array}$ \\
\hline
\end{tabular}

A: should always be used; C-1: use in first-line therapy justified; D: moderate evidence of lack of efficacy or unacceptably high risks, should generally not be offered; I: Evidence from $\geq 1$ properly randomized, controlled trials; Il: evidence from more than one well-planned non-randomized clinical trial, from cohort or case-controlled analytic studies (preferably at several sites); III-2: only one retrospective, non-controlled study or retrospective evaluation. (Evidence and recommendations graded according to the $2005 \mathrm{NIH}$ Consensus.) CNI: calcineurin inhibitors (cyclosporine, tacrolimus); GI: gastrointestinal; CR: complete remission; SE: side effect; NIH: US National Institutes of Health; MMF: mycophenolate mofetil

If specific symptoms of cGVHD are absent, histological confirmation of diagnosis may be required (7). This is particularly the case in gastrointestinal and nonspecific cutaneous manifestations but may be also required in hepatic and pulmonary involvement.

The severity of manifestations affecting individual organs is determined on the extent of organ function impairment due to cGVHD. Mild cGVHD is characterized by typical mild alterations indicating cGVHD with no effect on organ function; moderate cGVHD is associated with moderate organ alterations with mild impairment of organ function; and severe organ alterations are characterized by significant impairment of organ function. Overall severity is calculated on the basis of the number of organs affected and the severity of their involvement (Table 1) (6).

\section{Treatment}

\section{First-line therapy}

First-line treatment (Table 2) consists of steroids given alone or in combination with calcineurin inhibitors, and is based on randomized trials (8). As mild cGVHD does not impair organ function, the use of topical immunosuppressants (topical steroids, topical calcineurin inhibitors, or phototherapy) should be considered. If this is impossible, prednisone treatment at an initial dose of 0.5 to $1 \mathrm{mg} / \mathrm{kg}$ body weight/day is recommended (8). Topical immunosuppressants can be used in addition to systemic immunosuppression, to improve efficacy, or to reduce systemic immunosuppression, but lack systemic efficacy. For moderate or severe cGVHD, systemic treatment with prednisone or methylprednisolone at an initial dose of $1 \mathrm{mg} / \mathrm{kg}$ body weight/day should be used. In individual cases lower doses of 0.5 to $1 \mathrm{mg} / \mathrm{kg}$ may be used (8).

The combination of steroids with a calcineurin inhibitor (CNI) (cyclosporine or tacrolimus) is particularly worth considering for severe cGVHD. As cGVHD often takes time to respond to immunosuppressive treatment, response should not be assessed until at least 8 weeks have elapsed, or until 3 to 6 months have elapsed in the presence of deep cutaneous sclerosis. Long-term immunosuppressant treatment lasting at least 3 to 6 months is often required. Dose reduction of immunosuppressive agents should be performed stepwise.

Depending on the patient population, first-line therapy achieves complete remission of cGVHD in approximately $20 \%$ (adults) to $50 \%$ (children) of cases (9). If symptoms progress during the first 4 weeks of first-line therapy or there is no improvement in symptoms within 8 to 12 weeks, second-line therapy should be initiated.

\section{Second-line therapy}

While first-line therapy is based on randomized trials, for second-line therapy only phase II trials and retrospective analyses are available (10). In addition, because the data on disease severity and patient populations are very heterogeneous (in terms of age, conditioning, and stem cell source) the published response rates can not be fully extrapolated to the majority of patients currently treated for cGVHD. Moreover, many substances (Table 3) have been used almost exclusively in combination with steroids. 
Second-line therapy for chronic graft-versus-host disease (cGVHD) (according to [9])

\begin{tabular}{|c|c|c|c|c|c|}
\hline Treatment & $\begin{array}{l}\text { Recommen- } \\
\text { dation grade }\end{array}$ & $\begin{array}{l}\text { Level of } \\
\text { evidence }\end{array}$ & $\begin{array}{l}\text { Response } \\
\text { rate }\end{array}$ & $\begin{array}{l}\text { Side effects in more } \\
\text { than } 25 \% \text { of treated } \\
\text { patients }\end{array}$ & Comments \\
\hline Steroids & B & || $\mid-1$ & $\mathrm{n} / \mathrm{a}$ & $\begin{array}{l}\text { Osteoporosis, osteonecro- } \\
\text { sis, diabetes mellitus }\end{array}$ & Of central importance \\
\hline Photopheresis & C-1 & II & $\begin{array}{l}\sim 60 \text { to } 70 \% \\
\sim 30 \% \mathrm{CR}\end{array}$ & $\begin{array}{l}\text { Infections of the central } \\
\text { venous access } \\
\text { (if applicable) }\end{array}$ & $\begin{array}{l}\text { Venous access required, steroid-saving effect, } \\
\text { good tolerability }\end{array}$ \\
\hline $\begin{array}{l}\text { mTOR inhibitors } \\
\text { (sirolimus, everolimus) }\end{array}$ & C-1 & || $\mid-1$ & $\begin{array}{l}\sim 60 \% \\
\sim 20 \% \mathrm{CR}\end{array}$ & $\begin{array}{l}\text { Transplant-associated } \\
\text { microangiopathy, hyperlip- } \\
\text { idemia, hematotoxicity }\end{array}$ & $\begin{array}{l}\text { Increased risk of micro-angiography when com- } \\
\text { bined with CNI, regular examination of blood levels } \\
\text { required }\end{array}$ \\
\hline MMF & C-1 & || $\mid-1$ & $\begin{array}{l}\sim 50 \% \\
\sim 10 \% \mathrm{CR}\end{array}$ & $\begin{array}{l}\text { GI SEs, risk of infection } \\
\text { (viral) and increased risk } \\
\text { of relapse }\end{array}$ & Steroid sparing activity \\
\hline $\begin{array}{l}\text { CNls (cyclosporine, } \\
\text { tacrolimus) }\end{array}$ & C-1 & || $\mid-1$ & $\mathrm{n} / \mathrm{a}$ & $\begin{array}{l}\text { Renal toxicity, } \\
\text { hypertension }\end{array}$ & $\begin{array}{l}\text { Reduces steroid use, examination of blood levels } \\
\text { required }\end{array}$ \\
\hline MTX & $\mathrm{C}-2$ & || $\mid-1$ & $\begin{array}{l}\sim 50 \% \\
\sim 10 \text { to } 20 \% \\
\mathrm{CR}\end{array}$ & Hematotoxicity & $\begin{array}{l}\text { Best results in mucocutaneous cGVHD, reduces } \\
\text { steroid use, contraindicated in the presence of } \\
\text { pleural effusions or ascites }\end{array}$ \\
\hline High-dose steroid & C-2 & || $\mid-2$ & $\begin{array}{l}50 \text { to } 75 \% \\
\text { (PR only) }\end{array}$ & Risk of infection & Rapid control of cGVHD \\
\hline $\begin{array}{l}\text { Thoracoabdominal } \\
\text { radiation }\end{array}$ & $\mathrm{C}-2$ & || $\mid-2$ & $\begin{array}{l}\sim 50 \% \\
\sim 25 \% \mathrm{CR}\end{array}$ & Hematotoxicity & $\begin{array}{l}\text { Best results for fasciitis and mucocutaneous } \\
\text { cGVHD }\end{array}$ \\
\hline Hydroxychloroquine & $\mathrm{C}-2$ & || $\mid-2$ & $\begin{array}{l}\sim 25 \% \\
\sim 10 \% \mathrm{CR}\end{array}$ & GI side effects & $\begin{array}{l}\text { Best results for mucocutaneous and hepatic } \\
\text { cGVHD }\end{array}$ \\
\hline Clofazimine & $\mathrm{C}-2$ & || $\mid-2$ & $\begin{array}{l}\sim 50 \% \\
\text { (PR only) }\end{array}$ & $\begin{array}{l}\text { Gl side effects, hyperpig- } \\
\text { mentation }\end{array}$ & Best results for mucocutaneous cGVHD \\
\hline Pentostatin & $\mathrm{C}-2$ & II & $\begin{array}{l}\sim 50 \% \\
\sim 10 \% \mathrm{CR}\end{array}$ & $\begin{array}{l}\text { Hematotoxicity, risk of } \\
\text { infection }\end{array}$ & Best results in children \\
\hline Rituximab & $\mathrm{C}-2$ & II & $\begin{array}{l}\sim 50 \% \\
\sim 10 \% \mathrm{CR}\end{array}$ & Risk of infection & $\begin{array}{l}\text { Effective in manifestations associated with auto- } \\
\text { antibodies and sclerodermoid cutaneous involve- } \\
\text { ment }\end{array}$ \\
\hline Imatinib & $\mathrm{C}-2$ & || $\mid-1$ & $\begin{array}{l}\sim 50 \% \\
\sim 20 \% \mathrm{CR}\end{array}$ & Fluid retention & $\begin{array}{l}\text { Efficacy demonstrated mainly in sclerodermoid } \\
\text { cGVHD and bronchiolitis obliterans }\end{array}$ \\
\hline Thalidomide & C-3 & II & $\begin{array}{l}\sim 20 \text { to } 30 \% \\
\text { (PR only) }\end{array}$ & $\begin{array}{l}\text { Neurotoxicity, drowsiness, } \\
\text { constipation }\end{array}$ & $\begin{array}{l}\text { Treatment for simultaneous cGVHD and recurrent } \\
\text { multiple myeloma }\end{array}$ \\
\hline Azathioprine & C-3 & || $\mid-1$ & $\mathrm{n} / \mathrm{a}$ & $\begin{array}{l}\text { Hematotoxicity, risk of } \\
\text { infection }\end{array}$ & $\begin{array}{l}\text { Increased risk of malignant disease of the oral } \\
\text { mucosa }\end{array}$ \\
\hline Retinoids & C-3 & || $\mid-2$ & $\begin{array}{l}\sim 60 \% \\
\text { (PR only) }\end{array}$ & $\begin{array}{l}\text { Skin toxicity, } \\
\text { hyperlipidemia }\end{array}$ & Effective in sclerodermoid cutaneous involvement \\
\hline Alemtuzumab & C-4 & III-3 & $\mathrm{n} / \mathrm{a}$ & Risk of infection & Last resort for refractory cGVHD \\
\hline Etanercept & C-4 & || $\mid-3$ & $\mathrm{n} / \mathrm{a}$ & Risk of infection & $\begin{array}{l}\text { May be used to treat mixed acute and chronic } \\
\text { GVHD or GI manifestations of CGVHD }\end{array}$ \\
\hline
\end{tabular}

B: should generally be used; C-1: use in second-line therapy justified; C-2: use after failure of second-line therapy justified; C-3: should only be used in specific circumstances, due to unfavorable risk profile; C-4: experimental, should only be used in clinical trials and individual cases; III-1: several reports from retrospective evaluations or small uncontrolled clinical trials: III-2: only one report from small uncontrolled clinical trial or retrospective evaluations; III-3: only case reports available (5) MMF: mycophenolate mofetil; CNI: calcineurin inhibitors; MTX: methotrexate; CR: complete remission; Gl: gastrointestinal; SE: side effect; n/a: not available 
Topical treatment options for chronic graft-versus-host disease (cGVHD) (according to [8])

\begin{tabular}{|c|c|c|c|c|c|c|}
\hline Organ & Drug & $\begin{array}{l}\text { Recom- } \\
\text { mendation } \\
\text { grade }\end{array}$ & $\begin{array}{l}\text { Evi- } \\
\text { dence } \\
\text { level }\end{array}$ & $\begin{array}{l}\text { Response } \\
\text { rate }\end{array}$ & Side effects & Comments \\
\hline \multirow[t]{5}{*}{ Skin } & Topical steroids & C-1 & || $\mid-1$ & $\mathrm{n} / \mathrm{a}$ & Skin atrophy & $\begin{array}{l}\text { Trunk and extremities: medium- and high- } \\
\text { potency steroids; face: hydrocortisone } 1 \%\end{array}$ \\
\hline & $\begin{array}{l}\text { Tacrolimus/ } \\
\text { pimecrolimus }\end{array}$ & C-1 & || $\mid-1$ & $\sim 70 \%$ & $\begin{array}{l}\text { Increased long-term risk of } \\
\text { cutaneous malignancies }\end{array}$ & Applied twice daily \\
\hline & PUVA & C-1 & || $\mid-1$ & $\sim 75 \%$ & $\begin{array}{l}\text { Phototoxicity, increased long-term } \\
\text { risk of cutaneous malignancies }\end{array}$ & Must not be combined with phototoxic drugs \\
\hline & UVA & C-1 & || $\mid-1$ & $\sim 60$ to $70 \%$ & $\begin{array}{l}\text { Phototoxicity, increased long-term } \\
\text { risk of cutaneous malignancies }\end{array}$ & $\begin{array}{l}\text { No UV protection needed after treatment, } \\
\text { must not be combined with phototoxic drugs }\end{array}$ \\
\hline & UVB & C-1 & || $\mid-2$ & $\sim 60 \%$ & $\begin{array}{l}\text { Phototoxicity, increased long-term } \\
\text { risk of cutaneous malignancies }\end{array}$ & Lack of efficacy in cutaneous sclerosis \\
\hline $\mathrm{GI}$ & Topical steroids & C-1 & || $\mid-1$ & $\sim 60$ to $70 \%$ & & Budesonide or beclomethasone \\
\hline Lung & Topical steroids & B & III-2 & $\sim 50 \%$ & & Can be combined with betamimetics \\
\hline \multirow[t]{3}{*}{ Oral mucosa } & $\begin{array}{l}\text { Topical tacrolimus/ } \\
\text { cyclosporine }\end{array}$ & $\mathrm{C}-2$ & || $\mid-1$ & $\sim 60 \%$ & $\begin{array}{l}\text { Potential long-term risk of malig- } \\
\text { nant disease of the oral mucosa }\end{array}$ & $\begin{array}{l}\text { Systemic drug levels possible, } \\
\text { with associated risk of renal toxicity }\end{array}$ \\
\hline & Topical steroids & C-1 & || $\mid-1$ & $\sim 60$ to $80 \%$ & $\begin{array}{l}\text { Risk of local infections (fungal, } \\
\text { viral) }\end{array}$ & Best results with budesonide \\
\hline & Topical PUVA & $\mathrm{C}-2$ & III-2 & $\sim 60$ to $70 \%$ & $\begin{array}{l}\text { Phototoxicity, long-term risk of oral } \\
\text { malignancy }\end{array}$ & Important option for refractory oral cGVHD \\
\hline \multirow[t]{2}{*}{ Eyes } & Topical steroids & C-1 & || $\mid-1$ & $\sim 60$ to $75 \%$ & $\begin{array}{l}\text { Risk of atrophy of the cornea and } \\
\text { infectious keratitis }\end{array}$ & $\begin{array}{l}\text { Better short-term tolerability, not for long- } \\
\text { term therapy }\end{array}$ \\
\hline & $\begin{array}{l}\text { Topical } \\
\text { cyclosporine }\end{array}$ & C-1 & || $\mid-1$ & $\sim 60 \%$ & $\begin{array}{l}\text { Local burning and stinging } \\
\text { sensation }\end{array}$ & $\begin{array}{l}\text { Fewer long-term side effects, higher long- } \\
\text { term efficacy than steroids }\end{array}$ \\
\hline \multirow[t]{2}{*}{ Vagina } & Topical steroids & B & III-3 & $\mathrm{n} / \mathrm{a}$ & $\begin{array}{l}\text { Increased risk of local infections } \\
\text { and atrophy }\end{array}$ & $\begin{array}{l}\text { Topical estrogen therapy and antifungal } \\
\text { prophylaxis recommended }\end{array}$ \\
\hline & $\begin{array}{l}\text { Topical tacrolimus/ } \\
\text { cyclosporine/ } \\
\text { pimecrolimus }\end{array}$ & B & |II-3 & $\mathrm{n} / \mathrm{a}$ & Burning & Poorer tolerability, higher long-term efficacy \\
\hline
\end{tabular}

B: should generally be used; C-1: use in first-line therapy justified; C-2: use after failure of second-line therapy justified; Ill-1: several reports from retrospective evaluations or small uncontrolled clinical trials; III-2: only one report from small uncontrolled clinical trial or retrospective evaluations; III-3: only case reports available (5)

GI: gastrointestinal; PUVA: psoralen plus UVA; n/a: not available

In general, no more than three immunosuppressive agents should be combined, as combinations of more drugs often does not lead to improved efficacy but results in a significantly increased risk of side effects and infections. Because of the substantial toxicity of longterm steroid treatment, strategies for dose reduction are very important. Since no predictors of response for a single agent in individual patients are yet available, the choice of agent depends mainly on side effect profiles and patients' medical history. The response rates for specific agents range between $20 \%$ and $70 \%$ (photopheresis). Certain drugs such as imatinib and retinoids are recommended only for manifestations associated with sclerosis (bronchiolitis obliterans [imatinib], sclerodermoid cutaneous alterations [retinoids, imatinib]), because of their specific mechanisms of action.

Response is assessed as for first-line therapy. Administration of drugs that have been shown to be ineffective should be stopped. As a rule, drugs shown to be ineffective should be tapered off stepwise with no more than one drug to be changed at a time in order to be able to evaluate their efficacy.

\section{Supportive therapy Infection prophylaxis}

Depending on the severity and type of immunosuppression, patients should receive one of the following prophylactic measures against infections.

The main pathogens are encapsulated bacteria such as pneumococci and Haemophilus influenzae. In addition to the need for vaccinations, lifelong antibiotic prophylaxis or rapid antibiotic treatment for airway infections is required, depending on the severity and type of immunosuppression. This is particularly true for Pneumocystis jiroveci pneumonia $(\mathrm{PjP})$ prophylaxis (level A-I recommendation); standard treatment is prophylactic trimethoprim/sulfamethoxazole (11).

When serum tests are positive for previous herpes simplex virus/varicella zoster virus infection, acyclovir ( $3 \times 200$ to $400 \mathrm{mg} /$ day) is recommended (B-II) to prevent reactivation during prolonged immunosuppression (12). 


\section{TABLE 5}

Immunizations following allogeneic bone marrow and blood stem-cell transplantation (according to [14])

\begin{tabular}{|c|c|c|c|c|}
\hline & Age & $\begin{array}{l}\text { Beginning of } \\
\text { vaccination } \\
\text { (months after } \\
\text { allogeneic HSCT) }\end{array}$ & $\begin{array}{l}\text { No. of doses } \\
\text { of vaccination }\end{array}$ & $\begin{array}{l}\text { Recommendation } \\
\text { grade }\end{array}$ \\
\hline \multicolumn{5}{|l|}{ Inactivated vaccines } \\
\hline $\begin{array}{l}\text { Diphtheria/tetanus/pertussis/ } \\
\text { Haemophilus influenza type } \\
\text { B/polio }\end{array}$ & Adults & 6 (booster after 18) & $3+1$ booster & $\begin{array}{l}\text { B II/ B III (whooping cough) } \\
\text { should generally be offered }\end{array}$ \\
\hline $\begin{array}{l}\text { Diphtheria/tetanus/pertussis/ } \\
\text { Haemophilus influenza type } \\
\text { B/polio/hepatitis B }\end{array}$ & Children & 6 (booster after 18) & $3+1$ booster & B II should generally be offered \\
\hline Tick-borne encephalitis & $\begin{array}{l}\text { Adults } \\
\text { Children }\end{array}$ & 12 & 3 & C III in areas at-risk \\
\hline $\begin{array}{l}\text { Hepatitis B } \\
\text { Hepatitis A }\end{array}$ & Adults & $\begin{array}{l}6 \text { to } 12 \\
6 \text { to } 12\end{array}$ & $\begin{array}{l}3 \\
3\end{array}$ & $\begin{array}{l}\text { B II should generally be offered } \\
\text { C III optional if risk }\end{array}$ \\
\hline Hepatitis A & Children & 12 & 3 & C III optional if risk \\
\hline Influenza & $\begin{array}{l}\text { Adults } \\
\text { Children }\end{array}$ & 4 to 6 & 1 & A Il annually \\
\hline Human papillomavirus & Girls aged 12 to 17 & 12 & 3 & Optional \\
\hline $\begin{array}{l}\text { Neisseria meningitidis } \\
\text { (conjugate) }\end{array}$ & $\begin{array}{l}\text { Adults } \\
\text { Children }\end{array}$ & 12 & 3 & C III \\
\hline $\begin{array}{l}\text { Streptococcus pneumoniae } \\
\text { (conjugate) }\end{array}$ & $\begin{array}{l}\text { Adults } \\
\text { Children }\end{array}$ & 6 (booster after 18) & $3+1$ booster & $\begin{array}{l}\text { A II (children)/ B I (adults) } \\
\text { should generally be offered }\end{array}$ \\
\hline \multicolumn{5}{|l|}{ Live vaccines } \\
\hline Measles, mumps, and rubella & Children (adults) & $>24$ & 1 to 2 & $\begin{array}{l}\text { B II (children), C II/ III (adults) } \\
\text { optional; immunocompetent } \\
\text { patients only! }\end{array}$ \\
\hline Varicella zoster virus & Children & $>24$ & 2 & $\begin{array}{l}\text { C III optional; immunocompetent } \\
\text { patients only! }\end{array}$ \\
\hline
\end{tabular}

A: should always be offered; $B$ : should generally be offered; C: optional; I: evidence from more than one properly randomized controlled trial; II: evidence from $\geq 1$ well-designed clinical trials without randomization, from cohort or case-controlled analytic studies (preferably at several sites); III: descriptive evidence based on clinical experience, retrospective analyses, case reports, and/or experts' opinions (5) 
If there is a history of tuberculosis or invasive aspergillosis, secondary prophylaxis using isoniazid (C-III) or antimycotics that are active against aspergillus should be used (B-I). Substitution of polyvalent immunoglobulins is recommended in the presence of $\operatorname{IgG}$ deficiency $(<400 \mathrm{mg} / \mathrm{dL})$ or immunoglobulin subclass deficiency and recurrent infection, as for patients with primary immunodeficiency (C-III) (5).

\section{Vaccinations}

Allogeneic HSCT leads to a loss of protective immunity to vaccine preventable diseases. In addition, immune reconstitution is slow and takes at least 1 to 2 years after transplantation (13). In cGVHD patients, immune reconstitution is delayed and lifelong immune deficiency may remain. As a result, live vaccines must not be administered until at least 2 years after transplantation and can only be applied in the absence of immunosuppression and cGVHD after consulting the transplantation center.

Therefore, primary immunization, usually starting six months after allogeneic HSCT, is recommended (Table 5 or www.gvhd.de). During the first two years, conjugate vaccines (which also achieve good vaccination success in infants) are preferred (14).

Local reactions, which are sometimes observed in adults as a result of increased antigen concentration (diphtheria, pertussis) are rarely seen in patients following allogeneic HSCT. Influenza vaccination is advisable starting 4 months after transplantation and should be repeated annually. The recommended vaccine substances achieve successful immunization even in immunosuppressed patients. While children should always receive vaccinations according to the recommended schedule (infection risk due to school attendance, faster immune reconstitution), in adults the start of vaccination may be postponed for a maximum of three months if improvement of the immune status is expected. Serum tests are needed to monitor the success of vaccination in patients receiving immunosuppression.

The measles, mumps, and rubella (MMR) vaccination rate among Germany's population is too low to guarantee protection due to immunization of all potential contacts (herd immunity). As children are at increased risk of measles, mumps, and rubella infection due to the low vaccination rate, MMR vaccination should be performed two years after allogeneic HSCT in children with successful immune regeneration and in the absence of immunosupressive treatment, after consulting the transplantation center.

Determination of the immune status before immunization is only necessary if live vaccines are to be used.

\section{Hormone replacement}

Hypergonadotropic hypogonadism caused by the toxicity of chemotherapy/radiation is observed in more than $90 \%$ of patients following allogeneic HSCT. Early, irre- versible menopause occurs in the majority of premenopausal women.

In addition, men may present with testosterone deficiency. Hormone replacement can be indicated for women, to avoid genitourinary symptoms caused by atrophy and possible vasomotor complaints. Potential risks (secondary malignancies, impaired liver function, risk of thrombosis) and contraindications (impaired liver function, breast or endometrial carcinoma) must be taken into account (B-III-1) (15).

Hypothyroidism is also frequently observed. Regular tests of thyroid function, annual ultrasound examinations following radiation treatment, and possibly hormone replacement are therefore required. Long-term steroid use can cause secondary adrenal insufficiency, and corticosteroid (hydrocortisone) replacement may be indicated.

\section{Osteoporosis and osteonecrosis}

Patients with cGVHD often have several risk factors for osteoporosis. These include:

- High-dose chemotherapy

- Long-term steroid use

- Immobility

- Hypogonadism

- Steroid-induced diabetes mellitus

- Malabsorption syndrome.

As a result, the incidence of osteopenia (T score -1.0 to -2.5 ) and subsequent osteoporosis ( $\mathrm{T}$ score $<-2.5$ ) in patients with cGVHD is between $24 \%$ and $40 \%$ (16). There is also an increased rate of osteonecrosis in the axial skeleton (humerus, femur, tibia), caused by impaired microcirculation. Annual osteodensitometry is therefore recommended for all patients starting one year after allogeneic HSCT, and before and during steroid treatment. The value of osteodensitometry during bisphosphonate treatment is unclear.

All patients receiving steroid treatment should receive calcium (1 to $1.5 \mathrm{~g} /$ day) and vitamin D substitution (1000 IU/day) (17). If osteodensitometry reveals osteoporosis, bisphosphonate treatment should be administered (level B-I recommendation). As cGVHD patients are more likely to suffer side effects from oral bisphosphonates, intravenous administration is preferred.

Avascular osteonecrosis occurs independently of osteoporosis. The best method for diagnosis is magnetic resonance imaging of the affected area. There is no specific prophylaxis for osteonecrosis beside avoiding long-term steroid treatment.

\section{Psychosocial aspects, rehabilitation}

cGVHD is associated with considerable impairment of quality of life and physical functioning $(18,19)$. This is particularly true in patients with severe cGVHD (20). Physiotherapy is advisable for maintaining and restoring physical functioning (21). The following indications exist:

- Maintaining joint mobility in the presence of sclerosis of the fasciae and joints 
- Maintaining normal breathing in the presence of pulmonary involvement (respiratory therapy)

- Improving endurance and muscle strength in steroid myopathy

- Muscle strengthening in osteoporosis (22).

Patients with cGVHD also have a higher prevalence of psychological comorbidity, particularly depression, requiring psycho-oncological or psychiatric treatment. Targeted rehabilitation is extremely important in restoring physical functioning and the ability to work, and should be provided in specialized institutions (expert recommendations).

\section{Pediatric cGVHD}

The clinical manifestations of cGVHD in children and adolescents are similar to those in adults, but incidence is lower and the course is usually milder (23). Clinical course, diagnosis, and treatment have some specific features in pediatric patients (24). Ocular involvement should be diagnosed by an ophthalmologist experienced in the treatment of children, as complaints are reported less frequently and it is often impossible to perform Schirmer's test.

Malnutrition and enteral fluid loss in small children require regular monitoring of fluid and electrolyte levels. Pulmonary function should be assessed by pulmonologists with experience with pediatric patients. Body plethysmography can be performed in children as young as four years old.

In principle, there is no difference between cGVHD treatment for children and adults. However, long-term steroid therapy in children causes major side effects in terms of growth, bone density, osteonecrosis, and organ development, making agents that reduce steroid use, entailing the use of topical drugs, particularly important. In small children, the risk of systemic effects of

\section{KEY MESSAGES}

- Chronic graft-versus-host disease (cGVHD) is a multisystem disease caused by impaired tolerance mechanisms following hematopoetietic stem cell transplantation and is associated with significant morbidity and mortality.

- First-line therapy of cGVHD consists of steroids, which may be combined with a calcineurin inhibitor or mycophenolate if required.

- If first-line therapy of cGVHD fails, there are various treatment options available. Steroids remain important in second-line therapy.

- Immune deficiency associated with cGVHD requires prophylactic strategies against infections, and immediate pharmacological intervention if infection occurs.

- Supportive treatment (prevention and treatment of osteoporosis, hormone replacement therapy, physiotherapy) is essential. topical steroid and calcineurin inhibitor treatment must be considered.

\section{Conclusion}

Due to the involvement of multiple organs, treatment of chronic GVHD following allogeneic HSCT is challenging and requires a multidisciplinary approach that involves the transplantation center.

\section{Conflict of interest statement}

Prof. Wolf has received consultancy fees and reimbursement of travel expenses from Dr. Falk Pharma. He has received study funding from Novartis $\mathrm{GmbH}$ and third-party funds from Therakos.

Prof. Greinix has received lecture and consultancy fees from Therakos.

Prof. Holler has received consultancy fees and reimbursement of travel expenses from Fresenius Hemocare and Novartis GmbH. He has also received lecture fees from Amgen $\mathrm{GmbH}$.

Prof. Bertz, Dr. Lawitschka, and Dr. Halter declare that no conflict of interest exists.

Manuscript received on 11 October 2010, revised version accepted on 8 March 2011.

Translated from the original German by Caroline Devitt, MA.

\section{REFERENCES}

1. Akpek G, Zahurak ML, Piantadosi S, et al.: Development of a prognostic model for grading chronic graft-versus-host disease. Blood 2001; 97: 1219-26.

2. Lee SJ, Klein JP, Barrett AJ, et al.: Severity of chronic graft-versushost disease: association with treatment-related mortality and relapse. Blood 2002;100: 406-14.

3. Lee SJ, Vogelsang G, Flowers ME: Chronic graft-versus-host disease. Biol Blood Marrow Transplant 2003; 9: 215-33.

4. Ferrara JL, Levine JE, Reddy P, Holler E: Graft-versus-host disease. Lancet 2009; 373: 1550-61.

5. Couriel D: Ancillary therapy and supportive care of chronic graftversus-host disease: national institutes of health consensus development project on criteria for clinical trials in chronic Graft-versus host disease: V. Ancillary Therapy and Supportive Care Working Group Report. Biol Blood Marrow Transplant 2006; 12: 375-96

6. Filipovich AH, Weisdorf D, Pavletic S, et al.: National Institutes of Health consensus development project on criteria for clinical trials in chronic graft-versus-host disease: I. Diagnosis and staging working group report. Biol Blood Marrow Transplant 2005; 11: 945-56.

7. Greinix HT: Diagnosis and staging of chronic graft-versus-host disease in the clinical practice. Biol Blood Marrow Transplant 2011; 17: 167-75

8. Wolff D: Consensus conference on clinical practice in chronic graftversus-host disease (GVHD): first-line and topical treatment of chronic GVHD. Biol Blood Marrow Transplant 2010; 16: 1611-28.

9. Martin PJ, Storer BE, Rowley SD, et al.: Evaluation of mycophenolate mofetil for initial treatment of chronic graft-versus-host disease. Blood 2009; 113: 5074-82.

10. Wolff D, Schleuning M, von Harsdorf S, et al.: Consensus conference on clinical practice in chronic GVHD: second-line treatment of chronic graft-versus-host disease. Biol Blood Marrow Transplant 2011; $17: 1-17$

11. Podzamczer D, Salazar A, Jimenez J, et al.: Intermittent trimethoprim-sulfamethoxazole compared with dapsone-pyrimethamine for the simultaneous primary prophylaxis of pneumocystis pneumonia and toxoplasmosis in patients infected with HIV. Ann Intern Med 1995; 122: 755-61. 
12. Erard V, Wald A, Corey L, Leisenring WM, Boeckh M: Use of longterm suppressive acyclovir after hematopoietic stem-cell transplantation: impact on herpes simplex virus (HSV) disease and drugresistant HSV disease. J Infect Dis 2007; 196: 266-70.

13. Ljungman $P$, Cordonnier $C$, Einsele $H$, et al.: Vaccination of hematopoietic cell transplant recipients. Bone Marrow Transplant 2009; 44: 521-6.

14. Hilgendorf I: Vaccination of allogeneic haematopoietic stem cell transplant recipients: Report from the International Consensus Conference on Clinical Practice in chronic GVHD. Vaccine 2011; 29 : 2825-33.

15. Tauchmanova L, Selleri C, De RG, et al.: Estrogen-progestin therapy in women after stem cell transplant: our experience and literature review. Menopause 2007; 14: 320-30.

16. Tauchmanova L, Colao A, Lombardi G, Rotoli B, Selleri C: Bone loss and its management in long-term survivors from allogeneic stem cell transplantation. J Clin Endocrinol Metab 2007; 92: 4536-45.

17. Hautmann AH, Elad S, Lawitschka A, et al.: Metabolic bone diseases in patients after allogeneic hematopoietic stem cell transplantation: Report from the Consensus Conference on Clinical Practice in chronic GVHD. Transpl Int 2011; DOl: 10.1111/j.1432-2277.2011.01264.x (epub ahead of print).

18. Chiodi S, Spinelli S, Ravera G, et al.: Quality of life in 244 recipients of allogeneic bone marrow transplantation. Br J Haematol 2000 110: 614-9.

19. Fraser CJ, Bhatia S, Ness K, et al.: Impact of chronic graft-versushost disease on the health status of hematopoietic cell transplantation survivors: a report from the Bone Marrow Transplant Survivor Study. Blood 2006; 108: 2867-73.
20. Herzberg PY, Heussner P, Mumm FH, et al.: Validation of the human activity profile questionnaire in patients after allogeneic hematopoietic stem cell transplantation. Biol Blood Marrow Transplant 2010; 16: 1707-17.

21. Wiskemann J, Huber G: Physical exercise as adjuvant therapy for patients undergoing hematopoietic stem cell transplantation. Bone Marrow Transplant 2008; 41: 321-9.

22. Li L, Chan L, Gerber LH: Rehabilitation evaluation and treatment of patients with chronic graft-versus-host disease. In: Vogelsang GB, Pavletic SZ (eds.): Chronic Graft-verus-Host Disease. New York: Cambridge University Press, 2009: 252-67.

23. Zecca M, Prete A, Rondelli R, et al.: Chronic graft-versus-host disease in children: incidence, risk factors, and impact on outcome. Blood 2002; 100: 1192-1200.

24. Baird K, Wayne AS, Jacobsohn DA: Pediatric chronic graft-versushost disease. In: Vogelsang GB, Pavletic SZ (eds.): chronic graft versus host disease. New York: Cambridge University Press, 2009: $369-85$.

\section{Corresponding author}

Prof. Dr. med. Daniel Wolff

Abteilung für Hämatologie und Internistische Onkologie

Universität Regensburg

Franz-Josef Strauss Allee 11

93053 Regensburg, Germany

daniel.wolff@klinik.uni-regensburg.de

(Q) For eReferences please refer to: www.aerzteblatt-international.de/ref4311 


\section{REVIEW ARTICLE}

\section{The Treatment of Chronic Graft-Versus-Host Disease}

Consensus Recommendations of Experts From Germany, Austria, and Switzerland

Daniel Wolff, Hartmut Bertz, Hildegard Greinix, Anita Lawitschka, Jörg Halter, Ernst Holler

\section{eReferences}

e1. Gratwohl A: The EBMT activity survey 2008: impact of team size, team density and new trends. Bone Marrow Transplant 2011; 46: $174-91$.

e2. Grauer $\mathrm{O}$, Wolff D, Bertz $\mathrm{H}$, et al.: Neurological manifestations of chronic graft-versus-host disease after allogeneic haematopoietic stem cell transplantation: report from the Consensus Conference on Clinical Practice in chronic graft-versus-host disease. Brain 2010; 133: 2852-65.

e3. Travnik R, Beckers M, Wolff D, Holler E, Landthaler M, Karrer S: Graft-versus-Host Disease (GvHD)—an update: Part 1: Pathophysiology, clinical features and classification of GvHD. Hautarzt 2011; 62: 139-55.

e4. Dietrich T, Cursiefen C, Westekemper H, et al.: Consensus conference on clinical practice in chronic graft-versus-host disease (GVHD): Diagnosis and treatment of ocular chronic GVHD. Cornea 2011; in press.

e5. Meier JK, Wolff D, Pavletic S, et al.: Oral chronic graft-versus-host disease: report from the International Consensus Conference on clinical practice in cGVHD. Clin Oral Invest 2011; 15: 127-39.

e6. Tomas JF, Pinilla I, Garcia-Buey ML, et al.: Long-term liver dysfunction after allogeneic bone marrow transplantation: clinical features and course in 61 patients. Bone Marrow Transplant 2000; 26: 649-55. e7. Akpek G, Boitnott JK, Lee LA, et al.: Hepatitic variant of graftversus-host disease after donor lymphocyte infusion. Blood 2002; 100: 3903-7.

e8. Akpek G, Chinratanalab W, Lee LA, et al.: Gastrointestinal involvement in chronic graft-versus-host disease: a clinicopathologic study. Biol Blood Marrow Transplant 2003; 9: 46-51.

e9. Spinelli S, Chiodi S, Costantini S, et al.: Female genital tract graftversus-host disease following allogeneic bone marrow transplantation. Haematologica 2003; 88: 1163-8.

e10. Hildebrandt C, Fazekas T, Lawitschka A, et al.: Diagnosis and treatment of pulmonary chronic graft-versus-host disease: report from the International Consensus Conference on Clinical Practice in chronic GVHD. Bone Marrow Transplantation 2011; (epub ahead of print)

e11. Beredjiklian PK, Drummond DS, Dormans JP, Davidson RS, Brock GT, August C: Orthopaedic manifestations of chronic graft-versushost disease. J Pediatr Orthop 1998; 18: 572-5.

e12. Marks C, Stadler M, Häusermann P, et al.: German-AustrianSwiss Consensus conference on clinical practice in chronic GVHD: guidance for supportive therapy of chronic cutaneous and musculoskeletal graft-versus-host disease. Br J Dermatol 2011; 165: 18-29. 